\title{
TERIPANG SEBAGAI SALAH SATU SUMBER KOLAGEN
}

\author{
Bayu Kumayanjati ${ }^{*}$ \\ ${ }^{1}$ Balai Penelitian Teknologi Bahan Alam, Lembaga Ilmu Pengetahuan Indonesia \\ Jl. Jogja-Wonosari KM 31,5, Gading, Playen, Gunungkidul 55861 \\ *Alamat email: bayujati.dj@gmail.com
}

\begin{abstract}
Sea cucumbers are one of the Echinoderms that are rich in nutrients. Sea cucumbers contain a lot of minerals, unsaturated fatty acids, amino acids, and quite high protein. Protein content in sea cucumbers can reach $40 \%$ depending on the type and habitat of the sea cucumber. High protein content in sea cucumbers has the potential as a source of collagen. Collagen is a constituent protein found in the skin, tendons, cartilage and hard bones, and other tissues. Collagen currently has been widely applied in various industrial fields, such as cosmetics, health, pharmacy and food, so that the requirement for collagen will increase. Collagen currently is still dominated by collagen from cattle and pigs. Collagen from cattle is the most widely used in Indonesia because the halal collagen is important in Indonesia. The requirement for halal collagen will certainly be limited if it only relies on collagen from cattle. Therefore, alternative sources of collagen are needed, one of them is sea cucumbers.
\end{abstract}

Keywords: sea cucumbers, collagen, alternative.

\section{PENDAHULUAN}

Kolagen merupakan protein alami yang terdapat pada hewan vertebrata dan invertebrata. Pada vertebrata, kolagen merupakan konstituen protein yang terdapat pada kulit, tendon, tulang (tulang rawan maupun tulang keras), dan jaringan lainnya (Cheng et al., 2009; Huo \& Zhao, 2009) sedangkan pada hewan invertebrata kolagen merupakan bahan penyusun dinding tubuh. Kolagen termasuk protein fibrin (protein berbentuk serabut), yang berperan dalam pembentukan struktur sel terbesar pada matriks ekstraseluler yang mempertahankan bentuk jaringan. Secara umum, kandungan kolagen sekitar 25-35\% dari total protein pada tubuh vertebrata. Kolagen juga merupakan komponen organik pembangun tulang, gigi, sendi, otot, dan kulit (Peranginangin et al., 2014).

Teripang sebagai salah satu hewan invertebrata memiliki potensi kolagen yang cukup besar karena penyusun dinding tubuhnya adalah kolagen (Cui et al., 2007). Teripang telah dimanfaatkan dan dikonsumsi sejak berabad-abad lalu, terutama di Asia, karena kandungan nutrisinya yang sangat baik untuk kesehatan (Choo, 2008). Di negara Cina, tubuh dan kulit teripang jenis Stichopus japonicus telah dilaporkan secara medis berkhasiat menyembuhkan penyakit ginjal, paru-paru basah, anemia, anti inflamasi, dan mencegah arteriosklerosis serta penuaan jaringan tubuh. Di Korea dan Jepang, dinding tubuh (daging) dan organ dalam teripang juga dikonsumsi dengan acar, digoreng, atau dimakan mentah (Özer, 2004; Purcell, 2014). Di Indonesia, teripang juga telah dimanfaatkan sejak lama, terutama masyarakat di sekitar pantai sebagai bahan makanan. Sebagai bahan pangan, teripang mempunyai nilai gizi yang cukup tinggi dan rasanya lezat. Teripang 
olahan kering mempunyai kadar protein sekitar 82\%. Selain itu teripang juga mengandung asam lemak tidak jenuh jenis omega 3 yang sangat penting untuk kesehatan jantung (Martoyo et al., 2006).

\section{POTENSI TERIPANG}

Ada lebih dari 1.000 jenis teripang di dunia. Di Indonesia terdapat 350 spesies teripang dimana 54 spesies diantaranya adalah kelompok yang diperdagangkan. Namun dari 54 spesies tersebut, baru 33 spesies yang sudah divalidasi penamaannya secara taksonomi (Setyastuti \& Purwanti, 2015). Terdapat 22 jenis yang dapat dikonsumsi, delapan di antaranya memiliki nilai pasar yang cukup tinggi. $\mathrm{Ke}-8$ jenis tersebut adalah teripang pasir (Holothuria scabra), teripang susuan atau koro $(H$. nobilis dan $H$. fuscogilva), teripang batu (Actinopyga echinites), teripang bilabo (A. lecanora), teripang lotong (A. miliaris), teripang mata kucing (Bohadschia argus), dan teripang nanas (Theleonata ananas). Teripang memiliki sebaran yang cukup luas mengingat kawasan Indonesia banyak yang berkarakteristik perairan dangkal dan berpasir. Antara lain di perairan Pantai Madura, Bali, Lombok, Aceh, Bengkulu, Bangka, Riau, Belitung, Kalimantan, Sulawesi, Maluku, Nusa Tenggara, hingga ke Papua (Badan Riset dan Sumber Daya Manusia Kelautan dan Perikanan, 2019).

Teripang merupakan salah satu komoditas ekspor yang cukup penting dan bernilai ekonomis tinggi di Indonesia, hal ini dikarenakan banyak permintaan dari beberapa negara lain untuk dikonsumsi secara langsung atau dijadikan bahan baku obat. Negara tujuan ekspor yaitu Singapura, Hongkong, Cina, Korea, Jepang, Thailand, Amerika Serikat dan beberapa negara Eropa. Teripang sebagai komoditas perdagangan sebagian besar berasal dari hasil penangkapan dari laut. Sedangkan teknologi budidaya sebagai alternatif pemenuhan kebutuhan pasar belum dapat memberikan hasil yang optimal (Direktorat Konservasi dan Keanekaragaman Hayati Laut, 2015). Berdasarkan data dari Badan Pusat Statistik (BPS) yang disajikan dalam Gambar 1, nilai ekspor teripang dari tahun 2014-2019 mengalami fluktuatif, dengan nilai ekspor tertinggi terjadi di tahun 2016 yang mencapai $1.400 .000 \mathrm{~kg}$ (1400 ton). Selain potensi teripang di alam yang masih cukup besar, sektor budidaya juga merupakan potensi yang besar untuk ketersediaan teripang.

\section{KANDUNGAN NUTRISI TERIPANG}

Teripang memiliki kandungan gizi yang cukup baik dan merupakan sumber protein yang tinggi. Dari sudut pandang gizi, teripang dianggap sebagai produk makanan yang berharga, karena mengandung nutrisi yang penting bagi fisiologi manusia. Komposisi organik dan non-organik teripang segar bervariasi tergantung pada spesies, musim, habitat, dan mungkin pada tahap ontogenesis. Tahap ontogenesis merupakan tahap perkembangan organisme sejak dari telur yang dibuahi hingga ke bentuk dewasanya (Khotimchenko, 2015). Kandungan protein dalam teripang dapat mencapai $40 \%$, pada penelitian (Oedjoe, 2017) dari beberapa spesies teripang yang dianalisa memiliki kandungan protein yang cukup tinggi yaitu berkisar $31,11 \%$ sampai $42,32 \%$, seperti yang tersaji pada Tabel 1 . 


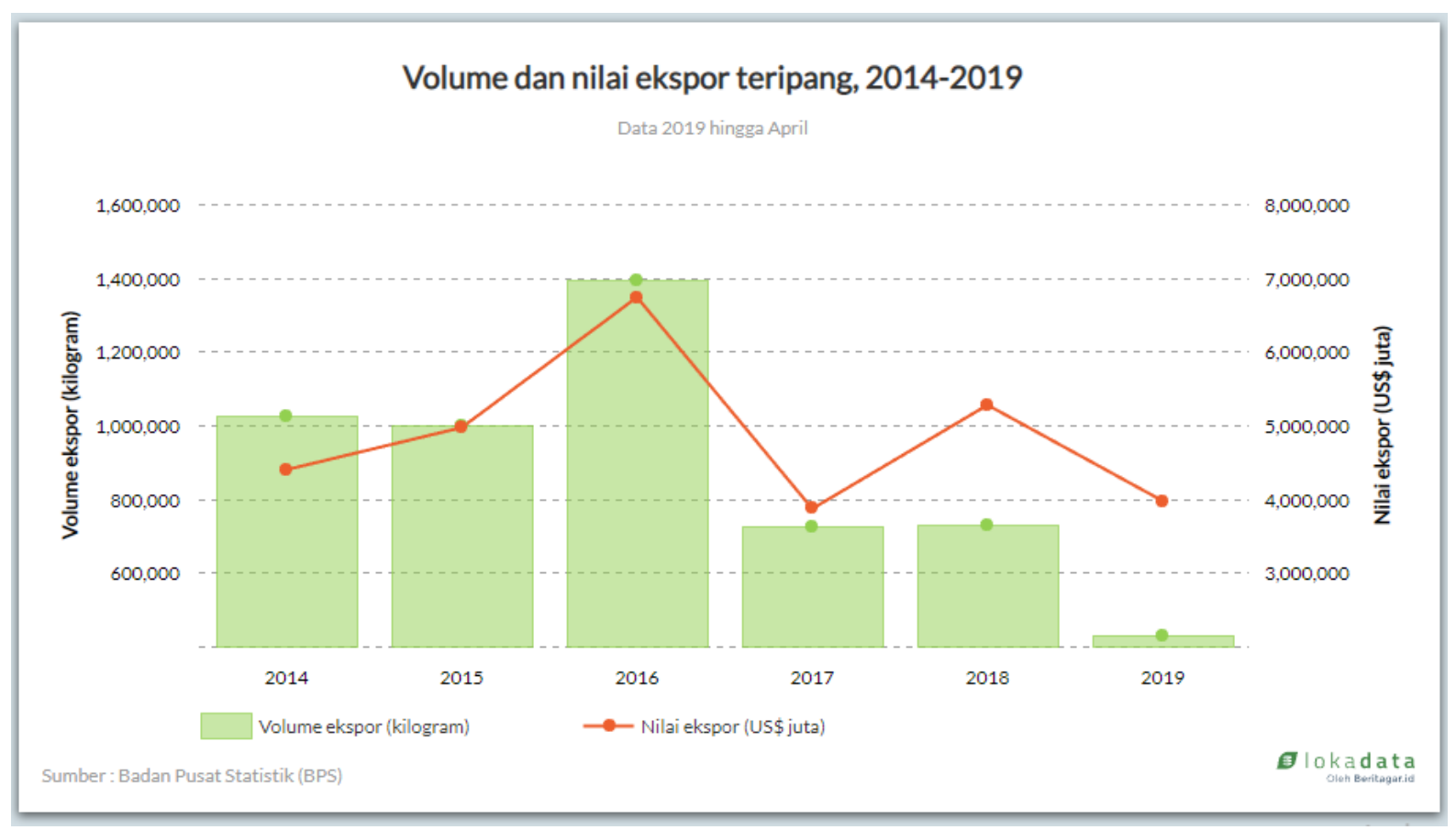

Sumber: Badan Pusat Statistik, 2019

Gambar 1. Volume dan Nilai Ekspor Teripang tahun 2014-2019.

Tabel 1. Kandungan nutrisi teripang yang ditemukan di perairan Kabupaten Sabu Raijua, Nusa Tenggara Timur.

\begin{tabular}{lccccc}
\hline \multirow{2}{*}{\multicolumn{1}{c}{ Spesies }} & \multicolumn{5}{c}{ Kandungan Nustrisi } \\
\cline { 2 - 6 } & Protein & Lemak & Karbohidrat & Abu & Air \\
\hline H. nobilis & 42,54 & 1,09 & 0,56 & 2,39 & 76,05 \\
H. scabra & 44,07 & 1,02 & 0,45 & 2,01 & 76,03 \\
H. atra & 43,32 & 1,12 & 0,87 & 2,38 & 78,34 \\
H. edulis & 41,61 & 1,08 & 1,14 & 2,47 & 78,16 \\
H. impatiens & 39,94 & 1,12 & 1,37 & 2,16 & 78,41 \\
H. leucospilota & 39,87 & 1,14 & 2,12 & 2,43 & 79,11 \\
Actinopyga lecanora & 31,11 & 1,14 & 2,31 & 2,35 & 79,24 \\
Bahaschia argus & 31,18 & 1,19 & 1,89 & 3,07 & 79,43 \\
Average & 39,08 & 1,12 & 1,34 & 2,42 & 78,10 \\
\hline Sumber: Oedjoe, 2017 & & & & &
\end{tabular}

Sumber: Oedjoe, 2017

Beberapa penelitian di beberapa lokasi melaporkan hasil analisa kandungan nutrisi dari beberapa jenis teripang seperti kadar air, kadar abu, protein dan lemak (Tabel 2).

Tingginya kandungan protein, menjadikan teripang memiliki potensi yang cukup besar sebagai sumber kolagen. Kolagen merupakan bagian dari protein yang memiliki banyak manfaat. Banyaknya kandungan kolagen dalam teripang dapat bervariasi tergantung dari jenisnya.

\section{KANDUNGAN KOLAGEN DALAM TERIPANG}

\section{Kolagen dari beberapa jenis teripang}

Sumber utama kolagen yang biasanya digunakan adalah dari mamalia darat seperti sapi, babi, domba ataupun unggas. 
Tabel 2. Kandungan Nutrisi teripang dari beberapa lokasi lainnya.

\begin{tabular}{|c|c|c|c|c|c|c|}
\hline \multirow{2}{*}{ Jenis teripang } & \multicolumn{6}{|c|}{ Kandungan Nutrisi (\%) } \\
\hline & Kadar Air & Protein & Lemak & Kadar abu & Lokasi & Referensi \\
\hline $\begin{array}{l}\text { H. tubulosa } \\
\text { H. polii } \\
\text { H. mammata }\end{array}$ & $\begin{array}{c}81,24- \\
85,24\end{array}$ & $\begin{array}{c}7,88- \\
8,82\end{array}$ & $\begin{array}{c}0,09- \\
0,18\end{array}$ & $\begin{array}{c}5,13- \\
7,85\end{array}$ & Laut Aegea & $\begin{array}{l}\text { (Aydin et al., } \\
\text { 2011) }\end{array}$ \\
\hline $\begin{array}{l}\text { H. pavra } \\
\text { H. arenicola }\end{array}$ & $\begin{array}{c}67,82- \\
69,45\end{array}$ & $\begin{array}{c}17,61- \\
24,37\end{array}$ & $\begin{array}{c}2,43- \\
2,88\end{array}$ & $\begin{array}{c}10,86- \\
32,74\end{array}$ & Teluk Persia & $\begin{array}{l}\text { (Salarzadeh et } \\
\text { al., 2012) }\end{array}$ \\
\hline H. scabra & $\begin{array}{c}84,54- \\
87,21\end{array}$ & $\begin{array}{c}5,78- \\
9,53\end{array}$ & $\begin{array}{c}0,17- \\
0,37\end{array}$ & $\begin{array}{l}3,59- \\
11,06\end{array}$ & $\begin{array}{l}\text { Laut } \\
\text { Marmara }\end{array}$ & (Özer, 2004) \\
\hline $\begin{array}{l}\text { Parastichopus } \\
\text { californicus } \\
\text { Cucumaria } \\
\text { frondosa }\end{array}$ & $\begin{array}{c}84,5- \\
90,1 \\
87,4- \\
90,1\end{array}$ & - & - & - & Uyak Bay & $\begin{array}{l}\text { (Zhong et al., } \\
\text { 2007) }\end{array}$ \\
\hline
\end{tabular}

Di Indonesia kolagen dari sapi dan ayam sangat banyak diproduksi, akan tetapi muncul kekhawatiran adanya penyakit hewan yang terjadi 10 tahun terakhir di negara Asia, seperti penyakit madcow dan flu burung yang menyerang ternak dan unggas. Sejalan dengan itu jumlah kolagen dari babi yang beredar juga meningkat secara bertahap (Susanti et al., 2016). Itulah mengapa masalah sumber kolagen halal menjadi mendesak di masyarakat. Sumber kolagen halal yang dapat dijadikan alternatif bisa berasal dari biota laut, salah satunya adalah teripang.

Persentase kandungan kolagen dari berbagai jenis teripang dari beberapa lokasi telah banyak dilaporkan dengan hasil yang cukup beragam. Beberapa hasil penelitian mengenai persentase kolagen dari teripang yang dibandingkan dengan persentase kolagen dari sumber biota lain terangkum dalam Tabel 3.

Berdasarkan Tabel 3, kandungan kolagen dari teripang sangat bervariasi tergantung jenisnya. Kandungan kolagen terkecil dilaporkan oleh (Aminzadeh et al., 2014) dari jenis $H$. parva dengan nilai rendemen $7 \%$ (berdasarkan berat kering) dan dapat mencapai $72,2 \%$ seperti yang dilaporkan (Li et al., 2019) pada jenis teripang $H$. cinerascens. Faktor yang memengaruhi nilai rendemen yaitu perbe-

Tabel 3. Persentase kandungan kolagen beberapa jenis teripang dibandingkan kolagen dari biota lain.

\begin{tabular}{lcll}
\hline \multicolumn{1}{c}{ Jenis teripang } & Persentase (\%) & \multicolumn{1}{c}{ Lokasi } & \multicolumn{1}{c}{ Referensi } \\
\hline Stichopus variegatus & 16,4 & Lampung, Indonesia & (Susanti et al., 2016) \\
S. japonicus & 70 & Tokyo, Jepang & (Saito et al., 2002) \\
S. japonicus & 26,6 & Pulau Jeju, Korea & (Park et al., 2011) \\
Holothuria parva & 7 & Teluk Chabahar, Iran & (Aminzadeh et al., 2014) \\
Parastichopus californicus & 20 & Pulau Kodiak, Alaska & (Liu et al., 2009) \\
Bohadschia bivitatta & 65 & Trengganu, Malaysia & (Siddiqui et al., 2013) \\
Holothuria cinerascens & 72,2 & Kota Taichung, Taiwan & (Li et al., 2019) \\
\hline Kulit ikan patin & 17,3 & - & (Devi et al., 2017) \\
Kulit ikan gabus & 16 & - & (Singh et al., 2011) \\
Kulit ikan nila & 67,3 & - & (Li et al., 2019) \\
Kulit babi & 64,7 & - & (Li et al., 2019) \\
\hline
\end{tabular}


daan metode ekstraksi, lama waktu ekstraksi, perbandingan sampel dan pelarut, konsentrasi asam basa, dan jenis bahan baku yang digunakan (Potaros et al., 2009). Ketebalan dinding tubuh teripang juga dimungkinkan memengaruhi rendemen kolagen yang akan didapat. Dinding tubuh teripang yang tebal dapat mengandung jumlah protein kolagen yang tinggi pula (Siddiqui et al., 2013).

\section{Perbandingan kolagen teripang dengan sumber kolagen lainnya}

Penelitian untuk mendapatkan kolagen halal selain dari mamalia (sapi, kambing, babi) terus dilakukan seperti dari kulit ikan, tulang ikan, dan lain-lain. Dibandingkan dengan sumber kolagen lain (pada Tabel 3) seperti kulit ikan patin, kulit ikan gabus, kulit ikan nila dan dari kulit mamalia lain, persentase rendemen kolagen dari teripang cukup tinggi. Beberapa jenis teripang memiliki kandungan yang bahkan lebih tinggi dari sumber kolagen lain tersebut. Salah satunya kandungan kolagen pada teripang jenis $H$. cinerascens lebih tinggi dari kolagen mamalia (babi) yaitu sebesar 72,2\% dibanding 64,7\%, bahkan masih lebih tinggi dari kolagen kulit ikan nila sebesar $67,33 \%$. Hal ini menunjukkan bahwa dengan ekstraksi yang optimal, teripang dapat memberikan rendemen kolagen yang cukup besar.

\section{KOMPOSISI ASAM AMINO KOLAGEN TERIPANG}

Kualitas kolagen teripang dapat dilihat dari jumlah kandungan asam amino di dalamnya. Asam amino merupakan molekul penyusun protein dan kolagen adalah konstituen dari protein. Perbandingan kandungan asam amino kolagen dari beberapa jenis teripang terangkum dalam Tabel 4.

Tabel 4. Perbandingan kandungan asam amino kolagen jenis-jenis teripang dengan kolagen mamalia.

\begin{tabular}{|c|c|c|c|c|c|c|}
\hline \multirow{2}{*}{ Senyawa } & S. variegatus ${ }^{1}$ & H. parva ${ }^{2}$ & P. californicus $^{3}$ & S. japonicus $^{4}$ & Kulit sapi $^{5}$ & Kulit babi $^{6}$ \\
\hline & \multicolumn{6}{|c|}{ (Residu/1000 residu) } \\
\hline Aspartic acid & 58 & 50 & 77 & 59 & 45 & 44 \\
\hline Threonine & 37 & - & - & 33 & 18 & 16 \\
\hline Serine & 26 & 20 & 65 & 44 & 33 & 33 \\
\hline Glutamic acid & 111 & 74 & 111 & 109 & 75 & 72 \\
\hline Proline & 67 & 96 & 95 & 95 & 121 & 123 \\
\hline Glycine & 169 & 270 & 332 & 325 & 330 & 341 \\
\hline Alanine & 64 & 91 & 91 & 112 & 119 & 115 \\
\hline Valine & 18 & 18 & 99 & 23 & 21 & 22 \\
\hline Methionine & 8 & 5 & - & 9 & 6 & 6 \\
\hline Isoleucine & 15 & 4 & 23 & 21 & 11 & 10 \\
\hline Leucine & 23 & 16 & 25 & 18 & 23 & 22 \\
\hline Tyrosine & 12 & 4 & 10 & 5 & 3 & 1 \\
\hline Phenylalanine & 13 & 6 & 10 & 3 & 3 & 12 \\
\hline Lysine & 10 & 7 & 7 & 7 & 26 & 27 \\
\hline Histidine & 5 & - & 4 & 4 & 5 & 5 \\
\hline Arginine & 66 & 49 & 50 & 55 & 50 & 48 \\
\hline
\end{tabular}

Sumber: ${ }^{1}$ Susanti et al., 2016, ${ }^{2}$ Aminzadeh et al., 2014, ${ }^{3}$ Liu et al., 2009, ${ }^{4}$ Saito et al., 2002, ${ }^{5}$ GiraudGuille et al., 2000, ${ }^{6}$ Ikoma et al., 2003. 
Berdasarkan analisa asam amino dari kolagen teripang, terdeteksi cukup banyak senyawa asam amino. Senyawa glysine menunjukkan nilai yang paling tinggi dari seluruh senyawa yang terdeteksi, yaitu berkisar antara 169-332 untuk beberapa jenis teripang. Nilai tersebut mendekati nilai glysine dari sapi (330) dan babi (341). Dibandingkan dengan kolagen dari kulit mamalia seperti sapi dan babi senyawa asam amino kolagen teripang menunjukkan nilai yang lebih tinggi pada senyawa glutamic acid. yaitu berkisar 74-111 berbanding 72 dan 75 . Tingginya kandungan glutamic acid tersebut memberikan rasa gurih pada teripang (umami). Seperti penjelasan (Saito et al., 2002), kandungan karakteristik asam amino yang relatif tinggi seperti, glysine, hidroxyproline, dan hidroxylysine, menunjukkan keberadaan kolagen sebagai komponen protein utama. Dan tingginya kandungan glutamic acid menjadikan teripang sebagai sumber umami.

Tingginya rendemen dan kandungan asam amino menyebabkan teripang memiliki potensi yang cukup baik untuk dijadikan alternatif sumber kolagen. Selain diambil dari alam, teripang juga sudah mulai dibudidayakan seperti $H$. scabra. Meskipun tidak akan bisa mengganti $100 \%$ kebutuhan kolagen saat ini (dari mamalia), setidaknya teripang bisa menjadi alternatif sumber kolagen halal yang berasal dari laut.

\section{EKSTRAKSI KOLAGEN DARI TERIPANG}

Kolagen didapatkan dari tubuh teripang dengan cara ekstraksi. Modifikasi ekstraksi kolagen dari teripang telah banyak dilakukan. Ada beberapa tahapan yang perlu dilakukan dalam proses ekstraksi tersebut. Berikut ini beberapa metode ekstraksi dari beberapa penelitian untuk mendapatkan kolagen dari teripang:

1. Andirisnanti, 2012

Pada penelitian ini didapatkan ekstrak kolagen kasar. Proses ekstraksi kolagen kasar dilakukan dengan memadukan metode kerja dari (Trotter et al., 1995; Saito et al., 2002), sebagai berikut:

a. Sebanyak $100 \mathrm{~g}$ sampel dinding tubuh teripang ditambahkan dengan $1000 \mathrm{ml}$ akuades dan diaduk selama 30 menit pada suhu $4^{\circ} \mathrm{C}$.

b. Campuran disaring dan akuades dibuang, sampel kemudian ditambahkan akuades baru sebanyak $1000 \mathrm{ml}$ dan diaduk selama 1 jam pada suhu $4^{\circ} \mathrm{C}$.

c. Campuran disaring dan akuades dibuang, sampel ditambahkan dengan $1000 \mathrm{ml}$ larutan ekstraksi $(100 \mathrm{ml} \mathrm{HCl}$ 1M, $4 \mathrm{ml}$ EDTA 1M, dan $896 \mathrm{ml}$ akuades), kemudian diaduk selama 24 jam.

d. Setelah 24 jam, akan terbentuk suspensi kental dan dinding tubuh teripang sudah tidak utuh. Suspensi tersebut disaring dan disentrifugasi dengan kecepatan 4500 rpm selama 30 menit.

e. Selesai proses sentrifugasi kemudian diliofilisasi untuk mendapatkan crude collagen.

f. Persentase rendemen ekstrak kolagen kasar teripang dihitung menggunakan rumus:

$$
\text { Rendemen }(\%)=\frac{W i}{W o} \times 100 \%
$$

$\mathrm{Wi}=$ berat crude collagen hasil liofiliasi (gram)

Wo $=$ berat kering tubuh teripang (gram)

2. Alhana et al., 2015

Metode yang dilakukan pada penelitian ini adalah optimasi ekstraksi kolagen yang memodifikasi metode dari 
(Cui et al., 2007) melalui 3 tahapan proses, antara lain:

a. Pre-treatment

Daging teripang direndam menggunakan larutan $\mathrm{NaOH}$ untuk menghilangkan protein non kolagen, lemak, mineral, dan pigmen. Rasio daging dan larutan $\mathrm{NaOH}$ adalah 1:10 (b/v) dengan konsentrasi larutan sebesar $0,05 \%-0,3 \%$ selama 48 jam. Selesai perendaman, daging teripang dicuci dengan air mengalir hingga $\mathrm{pH}$ netral.

b. Hidrolisis

Selesai proses pre-treatment dilanjutkan dengan proses hidrolisis menggunakan larutan $\mathrm{CH}_{3} \mathrm{COOH}$ dengan konsentrasi $0,1 \%$ dan $0,3 \%$. Rasio daging dan larutan adalah 1:10 (b/v). Proses hidrolisis dilakukan selama 48 jam pada suhu chilling. Daging teripang kemudian dicuci dengan air mengalir hingga $\mathrm{pH}$ netral kembali.

c. Ekstraksi

Proses ekstraksi dilakukan dengan menggunakan akuades. Daging teripang dimasukkan ke dalam akuades selama 2 jam dengan rasio daging dan akuades adalah 1:2 (b/v) kemudian dipanaskan pada suhu $45^{\circ} \mathrm{C}$ untuk menghindari degradasi kolagen menjadi gelatin. Hasil ekstrak kemudian dikeringkan dengan freeze dryer.

\section{Fawzya et al., 2016}

Isolasi kolagen dilakukan melalui tahapan ekstraksi terlebih dahulu, mengikuti metode (Park et al., 2012) yang dimodifikasi. Alur proses isolasi kolagen disajikan dalam Gambar 2. Modifikasi dilakukan dengan menambahkan tahapan perendaman dalam alkohol untuk menghilangkan lemak. Selain itu penggunaan $\beta$-merkaptoetanol ditiadakan karena bersifat toksik, dan konsentrasi larutan perendam serta waktu perendaman disesuaikan berdasarkan pengamatan selama proses ekstraksi. Seluruh tahapan ekstraksi dilakukan pada kondisi dingin sekitar $4^{\circ} \mathrm{C}$. Diawali dengan pencucian, daging teripang kemudian dipotong kecilkecil dan direndam dalam aquades (1:10 $\mathrm{b} / \mathrm{v}$ ) sambil diaduk menggunakan stirrer selama 30 menit, untuk membersihkan daging teripang dari sisa-sisa isi perut dan pengotor lainnya. Perendaman aquades dilakukan 2 kali. Berikutnya akuades diganti dengan alkohol 50\% (1:2), diaduk selama 30 menit untuk menghilangkan lemak; lalu dicuci dengan aquades sampai $\mathrm{pH}$ netral. Perendaman berikutnya menggunakan 10 bagian volume campuran Tris-HCl 0,1 M dan 4 mM EDTA, selama 1 malam. Perendaman ini dimaksudkan untuk menjaga stabilitas $\mathrm{pH}$ dan mengurangi mineral.

Setelah dicuci dengan akuades, larutan perendam diganti dengan 10 bagian volume $0,1 \mathrm{M} \mathrm{NaOH}$ selama 2 hari, untuk menghilangkan protein-protein non kolagen; kemudian dicuci kembali dengan akuades. Selama perendaman $\mathrm{NaOH}$ sebaiknya dilakukan penggantian dengan larutan $\mathrm{NaOH}$ baru setiap 4-5 jam agar penghilangan protein non kolagen lebih efektif. Perendaman dengan $\mathrm{NaOH}$ diakhiri ketika larutan perendam secara kualitatif tidak mengandung protein, yang dicek menggunakan uji Biuret.

Selanjutnya dilakukan ekstraksi dengan 10 bagian volume asam asetat 0,5 M selama 2 hari, dan disaring menggunakan kain blacu. Filtrat yang mengandung kolagen dilakukan pengendapan garam melalui penambahan garam $\mathrm{NaCl}$ sampai dengan konsentrasi akhir $1 \mathrm{M}$ dan disimpan semalam, kemudian disentrifugasi dengan kecepatan $10.000 \mathrm{x} \mathrm{g}$ selama 60 menit. Pelet hasil sentrifugasi 


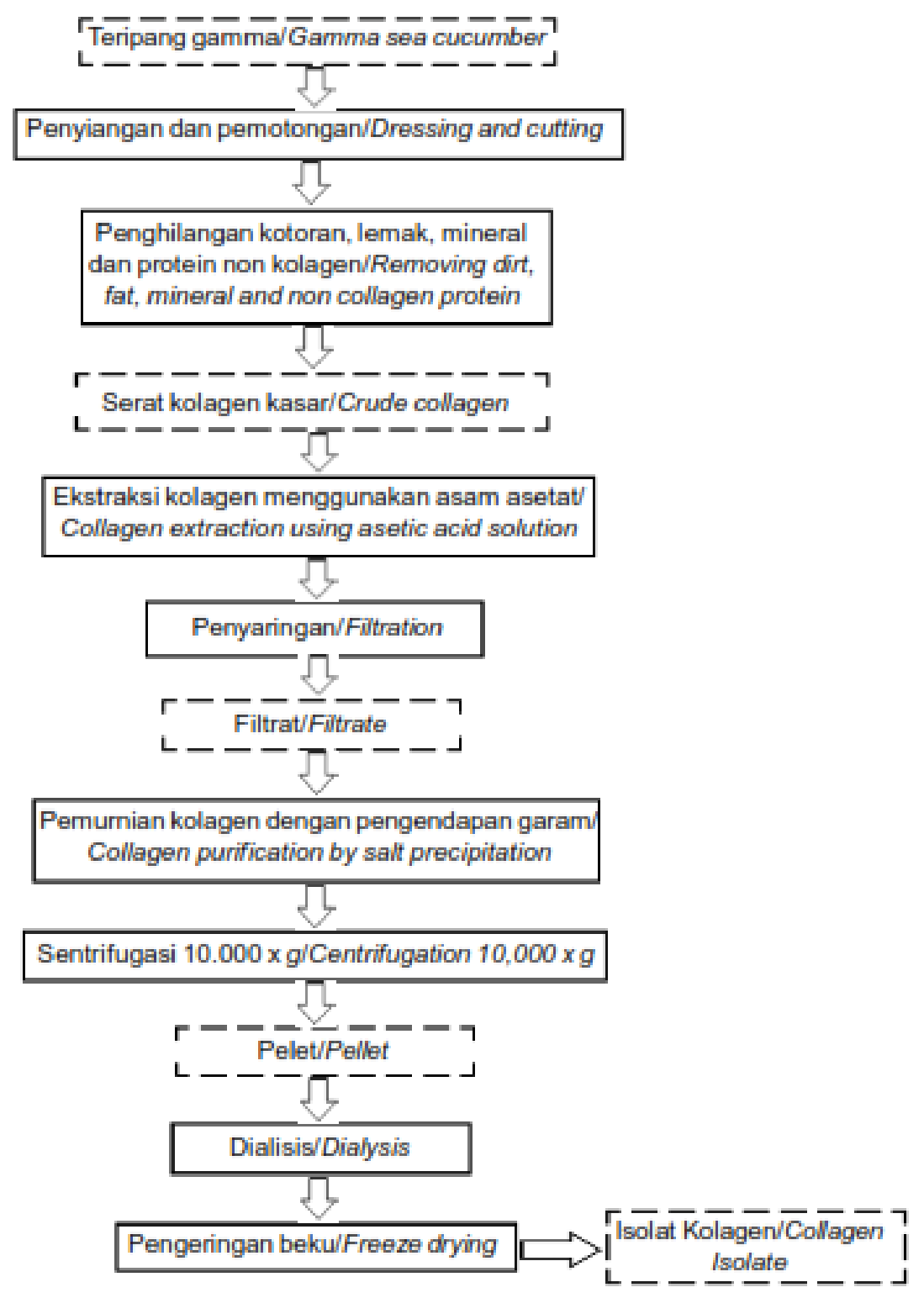

Gambar 2. Diagram alir proses isolasi kolagen (Fawzya et al., 2016).

dilarutkan dalam asam asetat $0,5 \mathrm{M}$ dan didialisis (kantung dialisis cut off 14.000) dengan bufer asetat $0,1 \mathrm{M}$ selama 1 malam, untuk menghilangkan garam-garam selama proses preparasi dan ekstraksi kolagen. Setiap 4 jam bufer diganti dan terakhir diganti dengan aquades. Selama proses dialisis, dan dengan mengganti cairan/pelarut beberapa kali, molekul garam terdifusi keluar kantong dialisis sehingga protein kolagen yang diperoleh lebih murni. Kolagen murni diperoleh melalui sentrifugasi, sebagai pelet yang kemudian dikeringbekukan.

4. Li et al., 2019

Ekstraksi kolagen didasarkan pada metode (Saito et al., 2002). Daging teripang kering dicuci dengan air suling, dipotongpotong, dan ditambahkan ke larutan dekomposisi yang mengandung $0,5 \mathrm{~N}$ $\mathrm{NaCl}, \quad 50 \mathrm{mM}$ EDTA, 0,2 $\mathrm{N} \quad \beta-$ mercaptoethanol dan $0,1 \mathrm{~N}$ Tris- $\mathrm{HCl}(\mathrm{pH}$ 8), campuran tersebut kemudian disentrifugasi pada kecepatan 8000 rpm 
dan ditambah dengan $0,1 \quad \mathrm{~N} \quad \mathrm{NaOH}$. Endapan yang terbentuk disentrifugasi lagi dan dibilas dengan air suling. Setelah sentrifugasi, supernatan ditambahkan ke pepsin (1 g / $100 \mathrm{~g}$ kolagen) dengan asam asetat $0,5 \mathrm{~N}$, disentrifugasi, dan $\mathrm{NaCl}$ ditambahkan ke konsentrasi akhir 0,6 M. Endapan dilarutkan kembali dalam asam asetat $0,5 \mathrm{M}$ dengan sentrifugasi, didialisis dengan 0,02 M Na2HPO4, dan disentrifugasi untuk melarutkan endapan dalam larutan asam asetat $0,5 \mathrm{M}$, kemudian didialisis dengan larutan asam asetat $0,1 \mathrm{M}$, selanjutnya dikeringbekukan untuk mendapatkan kolagen.

\section{PENUTUP}

Teripang dengan kandungan gizi yang kaya didalamnya telah banyak dimanfaatkan untuk dikonsumsi masyarakat. Kandungan mineral, protein dan asam amino esensialnya sangat baik untuk kecerdasan anak. Selain kandungan nutrisi yang tinggi, teripang memiliki potensi kolagen dengan rendemen yang cukup tinggi, karena sebagian besar penyusun dinding tubuhnya adalah kolagen. Kandungan senyawa asam amino di dalam kolagen teripang cukup banyak terdeteksi dan juga menunjukkan nilai yang cukup baik. Berdasarkan tingginya rendemen dan kandungan asam amino di dalam kolagen teripang tersebut, teripang memiliki potensi yang cukup besar untuk dijadikan alternatif sumber kolagen yang halal selain kolagen yang berasal dari sapi atau mamalia yang lain.

\section{DAFTAR PUSTAKA}

Alhana, Suptijah, P. \& Tarman, K. (2015). Ekstraksi dan karakterisasi kolagen dari teripang gamma. Jurnal Pengolahan Hasil Perikanan Indonesia, Vol.18 No.2: 150-161. doi.org/10.17844/jphpi.2015.18.2.15

0 .

Aminzadeh, S., Adibzadeh, N., Jamili, S., Karkhane, A.A., \& Farrokhi, N. (2014). Purification and Characterization of PepsinSolubilized Collagen from Skin of Sea Cucumber Holothuria parva. Appl Biochem Biotechnol, 173:143154. doi.org/10.1007/s12010-0140823-4.

Andirisnanti, W.A. (2012). Uji manfaat ekstrak kolagen kasar dari teripang Stichopus hermanii sebagai bahan pelembab kulit. [tesis]. Universitas Indonesia.

Aydin, M., Sevgili, H., Tufan, B., Emre, Y., \& Kose, S. (2011). Proximate composition and fatty acid profile of three different fresh and dried commercial sea cucumbers from turkey. Int J. Food Sci Tech, 46: 500508.

Badan Pusat Statistik. (2019). Volume dan Nilai Ekspor Teripang 2014-2019.

Badan Riset dan Sumber Daya Manusia Kelautan dan Perikanan. (2019). Domestikasi teripang yang bernilai tinggi. Laut Kita Masa Depan Bangsa, Edisi 02/2019: 44-47.

Cheng, F.Y., Hsu, F.W., Chang, H.S., Lin, L.C., \& Sakata, R. (2009). Effect of different acids on the extraction of pepsin-solubilised collagen melanin from silky fowl feet. Food Chemistry. 113: 563-567.

Choo, P.S. (2008). Population status, fisheries and trade of sea cucumbers in Asia. In V. Toral-Granda, A. Lovatelli and M. Vasconcellos (eds). Sea cucumbers. A global review of fisheries and trade. FAO Fisheries and Aquaculture Technical Paper. No. 516. Rome, FAO. pp. 81-118.

Cui, F.X., Chang, H.X., Zhao, J.L., Yong, Q.Z., Ping, D., Xue, Y.F., \& Xin, G. (2007). Characterization and subunit composition of collagen from the body wall of sea cucumber (Stichopus 
japonicus). Food Chemistry, 100: 1120-1125.

Devi, H.L.N.A., Suptijah, P., \& Nurilmala, M. (2017). Efektifitas alkali dan asam terhadap mutu kolagen dari kulit ikan patin. Jurnal Pengolahan Hasil Perikanan Indonesia. 20(2): 255265.

Direktorat Konservasi dan

Keanekaragaman Hayati Laut. (2015). Pedoman umum identifikasi dan monitoring populasi teripang. Direktorat Jenderal Pengelolaan Ruang Laut, Kementerian Kelautan dan Perikanan, ISBN: 978-602-791324-0, 69 Hlm.

Fawzya, Y.N., Chasanah, E., Poernomo, A., \& Khirzin, M.H. (2016). Isolasi dan karakterisasi parsial kolagen dari teripang gamma (Stichopus variegatus). JPB Kelautan dan Perikanan, Vol. 11 No. 1: 91-100.

Gelse, K., E. Poschl, \& T. Aigner. (2003). Collagens-structure, function, and biosynthesis. Advanced Drug Delivery Reviews, 55 (2003) 15311546.

Giraud-Guille, M.M., Besseau, L., Chopin, C., Durand, P., \& Herbage, D. (2000). Structural aspect of fish skin collagen which forms ordered arrays via liquid crystalline states. Biomaterials. Vol. 21, pp. 899-906.

Huo, J. \& Zhao, Z. (2009). Study on enzymatic hydrolysis of Gadus morrhua skin collagen and molecular weight distribution of hydrolysates. Agricultural Sciences in China 8 (6): 723-729.

Ikoma, T., Kobayashi, H., Tanaka, J., Walsh, D., \& Mann, S. (2003). Physical properties of type I collagen extracted from fish scale of Pagrus major and Orechromis niloticus. Int. J. Biol. Macromol, vol. 32, pp. 199204.

Khotimchenko, Y.S. (2015). The nutritional value of holothurians. Russian Journal of Marine Biology,
Vol. 41, No. 6: 409-423. doi.org/ 10.1134/S1063074015060061.

Li, P.H., Lu, W.C., Chan, Y.J., Ko, W.C., Jung, C.C., Hyunh, D.T.L., \& Ji, Y.X. (2019). Extraction and characterization of collagen from sea cucumber (Holothuria cinerascens) and its potential application in moisturizing cosmetics. Aquaculture, 515(734590): 1-8.

Liu, Z., Oliveira, A.C.M., \& Su, Y.C. (2009). Purification and characterization of pepsin-solubilized collagen from skin and connective tissue of giant red sea cucumber (Parastichopus californicus). Journal of agricultural and food chemistry, 58(2), 1270-1274.

Martoyo J., Aji N., \& Winanto T. (2006). Budidaya Teripang. Cet 6, edisi revisi. Penebar Swadaya, Jakarta. 76 hlm.

Oedjoe, M.D.R. (2017). Composition of nutritional content of sea cucumbers (Holothuroidea) in Mania Waters, Sabu Raijua Regency, East Nusa Tenggara. J Aquac Res Development 2017, 8(7): 1-3. doi.org/10.4172/ 2155-9546.1000502.

Özer, N.P., Mol, S., \& Varlik, C. (2004). Effect of handling procedures on the chemical composition of sea cucumber, Turk. J. Fish. Aquat. Sci., vol. 4, pp. 71-74.

Park, S.Y., Hee, K.L., Seogjae, L., Hyeong, C.H., Cho, M., \& Somi, K.C. (2011). Pepsin solubilized collagen (PSC) from red sea cucumber (Stichopus japonicas) regulates cell cycle and fibronectin synthesis in $\mathrm{HaCaT}$ cell migration. Food chemistry, 132, 487492.

Peranginangin, R., Murniyati., Nurhayati., \& Rahmad, W. (2014). Pengolahan kolagen dari kulit ikan nila. Penebar Swadaya, Jakarta. $60 \mathrm{hlm}$.

Potaros, T., Raksakulthai, N., Runglerdkreangkrai, J., \& Worawattanamateekul, W. (2009). Characteristics of collagen from nile 
tilapia (Oreochromis niloticus) skin isolated by two different methods. Kasetsart Journal-Natural Science. 43(3): 584-593.

Purcell, S.W. (2014). Value, market preferences and trade of Bechedemer from Pacific Island sea cucumbers, PLoS One, 9 (4): e 95075. doi.org/10.1371/journal.pone.00950 75.

Saito, M., Kunisaki, N., Urano, N., \& Kimura, S. (2002). Collagen as the major edible component of sea cucumber. The Journal of Food Science, 67: 1319-1322.

Salarzadeh, A., Afkhami, M., Bastami, K.D., Ehsanpour, M., Khzaali, A. \& Mokhleci, A. (2012). Proximate composition of two sea cucumber species Holothuria pavra and Holothuria arenicola in Persian Gulf. Annals of Biological Research, 3: 1305-1311.

Setyastuti, A. \& Purwanti, P. (2015). Species list of Indonesian trepang. SPC Beche-de-mer Information Bulletin, No.35: 19-24.

Shoulers, M.D. \& Raines, R.T. (2009). Collagen Structure and Stability. Annu. Rev. Biochem. 2009.78: 929958.

Silva, T.H., Moreira-Silva, Marques, A.L.P., Domingues, A., Bayon, I. \& Reis.L. (2014). Marine origin collagens and its potential applications. Mar Drugs. 2014 Dec; 12(12): 5881-5901. doi.org/ 10.3390/md12125881.

Singh, P., Benjakul, S., Maqsood, S., \& Kishimura, H. (2011). Isolation and characterization of collagen extracted from the skin of striped catfish (Pangasianodon hypophthalmus). Food Chemistry, 124: 97-105.

Susanti, L.Y., Khirzin, M.H., Sukarno, Yuliana, N.D., Chasanah, E., \& Fawziya, Y.N. (2016). Collagen from Sea Cucumber (Stichopus variegatus) as an Alternative Source of Halal Collagen. Proceeding The 1st IBSC: Towards The Extended Use Of Basic Science For Enhancing Health, Environment, Energy And Biotechnology. ISBN: 978-60260569-5-5: 111-113.

Tabarestani, S.H., Maghsoudlou, Y., Motamedzadegan, A., Mahoonak, A.R., \& Rostamzad, H. (2010). Study on some properties of acid soluble collagen isolated from fish skin and bones of rainbow trout (Onchorynchus mykiss). International Food Reseach Journal. 19(1): 251-257.

Trotter, J.A., Lyons-Levy, G., Thurmon, F. A., \& Koob, T.J. (1995). Covalent composition of collagen fibrils from the dermis of the sea cucumber, Cucumaria frondosa, a tissue with mutable mechanical properties. Comp Biochem Phycol, 112 A (3/4): 463-478.

Zhong, Y., Khan, M.A., \& Shahidi, F. (2007). Compositional characteristics and antioxidant properties of fresh and processed sea cucumber (Cucumaria frondosa). Journal of Agricultural and Food Chemistry, 55:1188-1192. doi.org/10.1021/ jf063085h. 